\title{
Plant biotech still a blot on Rüttgers' landscape
}

Although the German government continues to try to construct encouraging conditions for biotechnology, there is little sign that plant biotechnology will emerge from its cloud there soon.

In April 1997, the German government's Technologierat (technical advisory board) released a document outlining 94 recommendations for strengthening German biotechnology. Jürgen Rüttgers, Germany's enthusiastic Minister of Science and Technology, stated, "No other European location offers such good conditions." He considered that the unwillingness of the German public to accept biotechnology had been overcome.

However, some simple statistics in plant biotechnology indicate that that may not be entirely true. By the end of 1997, the number of field trials of genetically modified crops that had taken place in Germany-61-was one third fewer than the number of such trials conducted in much smaller countries such as The Netherlands and Belgium. France had

Ellen Peerenboom is a freelance writer working in Cologne, Germany. permitted 333 trials-more than five times as many field trials than Germany over the same period. The picture is less encouraging than even these numbers suggest because the relatively underdeveloped eastern German state, Mecklenburg Vorpommern, was host to about half of Germany's field trials.

Rüttgers commended the record of Mecklenburg Vorpommern in a statement in January saying that in areas that lacked sufficient industrial infrastructure, plant biotechnology offered "real opportunities." Simultaneously, he criticized Hessen, a state in western Germany, for its record on biotechnology. He blames Hessen's Green Party for hindering the development of gene technology and accuses them of worsening the situation by proposing to establish a university chair "devoted to the risks associated with gene technology."

Despite this, Germany's biotechnology advisory board now expects there to be expansion in the use of recombinant DNA technology in agriculture and the food industry. Because of this, Rüttgers wants to enhance consumer trust in plant biotechnology and genetically modified food through new education programs for the public and for schools.
In this regard, Rüttgers feels that the vague rules proposed by the European Commission (Brussels) in August 1997 covering the labeling of genetically modified food under the Novel Foods Directive are not helpful (Nature Biotechnology 15:1331, 1997). "Consumers [and industry] have been thrown by the European Commission," he warns. "We need clear rules. ... The competitiveness and reputation of the European food industry are in danger."

In addition, Rüttgers and the German health minister, Horst Seehofer, want to ease the strict German regulations on genetic engineering research experiments that bear no risk to the environment or to human health. Currently, these are considered as "Security Level 1" (S1) experiments under German law. This is the lowest safety level but full documentation of $\mathrm{S} 1$ experimental proposals is still required. The two ministers want to exempt these experiments from the bureaucracy that the law now requires. However, making this change will involve changing the European Union "contained use" directive (90/219).

Ellen Peerenboom
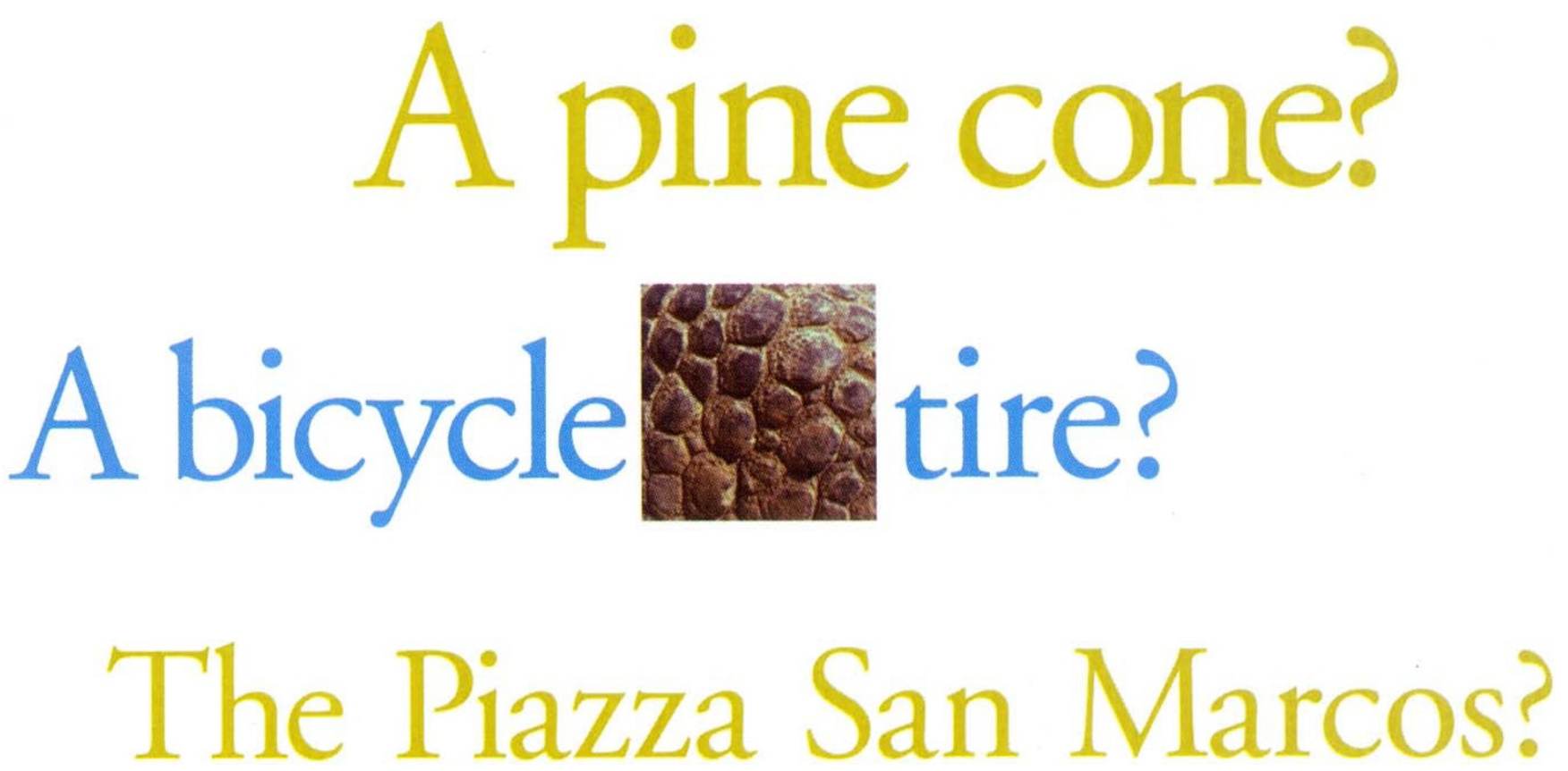